\title{
Tematyka szkolnictwa i edukacji średniowiecznej w czasopiśmiennictwie naukowym II RP
}

Pod koniec I wojny światowej - jak wynika z szacunków Jerzego Maternickiego $^{1}$ - działało w Krakowie 130 profesjonalnych historyków, we Lwowie ok. 120, w Warszawie ok. 90, w Poznaniu ok. 20, na Śląsku ogółem ok. 15, tylu samo w Toruniu, w Wilnie 10 historyków. Ci ludzie mieli tworzyć historiografię odrodzonego państwa polskiego. Odzyskanie niepodległości przez Polskę w listopadzie 1918 r. postawiło przed naszą nauką historyczną nowe, ogromne zadania. W II Rzeczpospolitej życie historyczne skupiło się głównie w Krakowie, Warszawie, Poznaniu, Wilnie i Lwowie. Na uniwersytetach zaczęły się tworzyć środowiska naukowców specjalizujących się w badaniach historyczno-pedagogicznych, jednak problematyką szkół i wychowania zajmowali się także historycy kultury oraz w interesującym nas aspekcie także mediewiści. Jeśli chodzi o historyków wychowania i szkolnictwa, prowadzili oni badania zwłaszcza w Krakowie - zarówno na Uniwersytecie Jagiellońskim, jak i w Komisji do Badania Historii Wychowania i Szkolnictwa w Polsce², na Uniwersytecie Jana Kazimierza we Lwowie ${ }^{3}$, na uniwersytecie wileńskim, ale także w nowo organizowanych w niepodległej Polsce uczelniach wyższych, a więc w powołanym w 1918 r. Katolickim Uniwersytecie

* Dr, Zakład Historii Wychowania, Wydział Studiów Edukacyjnych, Uniwersytet im. Adama Mickiewicza, 60-568 Poznań, ul. Szamarzewskiego 89.

1 J. Maternicki, Geografia historyczna // Rzeczypospolitej, „Przegląd Humanistyczny” 2 (1990), s. 11-45.

2 J. H e Il w i g, Prologomena do historii wychowania, Poznań 1995, s. 25 i n.

${ }^{3}$ W. S z u l a k i e w i c z, Dzieje nauczania historii oświaty i wychowania w Uniwersytecie Jana Kazimierza we Lwowie, „Acta Universitatis Nicolai Copernici”, Pedagogika XXIII, Historia wychowania, Toruń 2004, s. 11 i n. O roli Iwowskiego badacza dziejów wychowania - Stanisława Łempickiego w kształtowaniu się tamtejszego środowiska historyków wychowania zob.: t a ż, Udział Stanisława Łempickiego w kształtowaniu oblicza naukowego historii wychowania (W pięćdziesiątą rocznicę śmierci), [w:] Historia wychowania w XX wieku. Dorobek i perspektywy, red. T. G u m u ła, J. K r a s u s k i, S. M a j e w s k i, Kielce 1998, s. 77 i n.; zob. także J. C h o d a k o w s k a, Powstanie katedry pedagogiki w Uniwersytecie Jana Kazimierza we Lwowie, [w:] Historia wychowania w XX wieku, s. 361-367. 
Wileńskim, we Wszechnicy Piastowskiej w Poznaniư (późniejszym Uniwersytecie Poznańskim), w Wolnej Wszechnicy Polskiej w Warszawie ${ }^{5}$.

W nowych warunkach, mimo trudnej sytuacji ekonomicznej, nastąpił żywiołowy rozwój czasopiśmiennictwa naukowego, a także czasopiśmiennictwa o charakterze popularnonaukowym. Wiele z owych pism funkcjonowało stosunkowo krótko, i mimo niewątpliwych zasług dla propagowania najnowszego stanu badań, znikało szybko z rynku wydawniczego. Wśród periodyków naukowych i popularnonaukowych, poddanych kwerendzie na potrzeby tegoż artykułu znajdowały się zarówno te, które założono jeszcze w okresie rozbiorów, a których zawartość przeanalizowałem w innym miejscu ${ }^{6}$, jak i takie, które zawdzięczały swe powstanie intensyfikacji życia naukowego w niepodległej Polsce. Wśród tych pierwszych należy wymienić w pierwszym rzędzie „Kwartalnik Historyczny”, „Rocznik Krakowski”, „Szkołę”, „Muzeum”, „Przegląd Historyczny”, „Ateneum”, „Przegląd Pedagogiczny”, „Ateneum Kapłańskie”. To ostatnie czasopismo wychodziło od stycznia 1909 do grudnia 1918 r., a wznowione zostało dopiero w 1926 r. $^{7}$ Do nowych czasopism, które zostały objęte kwerendą zaliczyć należy „Przeszłość. Czasopismo Historyczne dla Wszystkich” wydawane w Poznaniu od roku 1929 do grudnia 1936 r. jako miesięcznik, „Kwartalnik Filozoficzny” ukazujący się od roku 1923, „Naukę Polską”, „Kulturę i Wychowanie” i szereg innych, uwzględnionych w przypisach. W 1928 r. rozpoczęto wydawanie „Oświaty i Wychowania”, w którym zamieszczano również sprawozdania bibliograficzne dotyczące dziejów szkolnictwa w Polsce ${ }^{8}$. Warto wspomnieć także o „Wiadomościach do Dziejów Wychowania i Szkolnictwa w Polsce”. Istotną rolę w popularyzowaniu wiedzy o przeszłości szkolnictwa i wychowania spełniała także „Minerwa Polska”, czasopismo ukazujące się jednak w krótkim czasie - w latach 1927-1929 - będące pierwszym polskim czasopismem historyczno-pedagogicznym ${ }^{9}$. Ogólnie rzecz biorąc, należy stwierdzić znaczącą intensyfikację badań historyczno-oświatowych w okresie międzywojennym, której tematyka wszakże skoncentrowana była na czasach najnowszych ${ }^{10}$. Również na polu badawczym historii średniowiecznej

${ }^{4}$ Na temat okoliczności powołania Uniwersytetu Poznańskiego i jego rozwoju w analizowanym okresie zob.: A. C z u b iń s k i, Utworzenie Uniwersytetu Poznańskiego i jego rozwój do 1922 roku, [w:] Alma Mater Posnaniensis. W 80. rocznicę utworzenia uniwersytetu w Poznaniu, red. P. H a u s e r, T. J a s iń s k i, J. To p o I s k i, Poznań 1999, s. 123 i n.; P. H a u s e r, T. K o tł o w s k i, Uniwersytet Poznański w latach 1923-1939, tamże, s. 135 i n.

5 J. Hell w i g, Dzieje historii wychowania w Polsce i jej twórcy (Próba zarysu historycznego), Poznań 2001, s. 63 i n.

${ }^{6} \mathrm{~K} . \mathrm{R}$ a t a j c z a k, Dzieje średniowiecznego szkolnictwa w polskich czasopismach naukowych XIX i początków XX wieku (do 1918 r.), [w:] Czasopiśmiennictwo XIX i początków XX wieku jako źródło do historii edukacji, red. I. M i c h a I s k a, G. M i c h a I s k i, Łódź 2010, s. 283-291.

7 Zob. bibliografię zawartości, „Ateneum Kapłańskie” 39 (1947).

${ }^{8}$ S. T ru c h i m, Historia szkolnictwa w Polsce. Przegląd prac ogłoszonych drukiem w latach 1930-1935, „Oświata i Wychowanie” 10 (1938), s. 329-345.

9 J. He ll w i g, Minerwa Polska (1927-1929) - jako pismo poświęcone historii wychowania, „Przegląd Historyczno-Oświatowy” 1998, nr 3-4, s. 222-229.

10 Zob. ogólnie charakterystykę historiografii historyczno-oświatowej: C. M a j o r e k, Polska historiografia oświatowa (1918-1939), [w:] Środowiska historyczne II Rzeczpospolitej, red. J. M a t e r n i c k i, Warszawa 1987; J. H e I I w i g, Dzieje historii wychowania w Polsce i jej twórcy..., s. 63 i n. 
nastąpiła intensyfikacja badań, jednakże głównie koncentrujących się na historii politycznej, gospodarczej, kształtowaniu się granic państwa polskiego, jego genezie, akcji chrystianizacyjnej itp.

W okresie od połowy XIX w. do roku 1918 w dziedzinie tematyki średniowiecznego szkolnictwa zauważyć można było dwa istotne zjawiska. Po pierwsze interesująca nas problematyka stanowiła jedynie ułamek ogólnej liczby publikacji poświęconych wiekom średnim, po drugie natomiast, autorami publikacji traktujących o dziejach szkół byli zarówno zawodowi historycy, jak i spory zastęp historyków-amatorów, rekrutujących się spośród nauczycieli gimnazjalnych i duchowieństwa ${ }^{11}$. Taki stan rzeczy może nieco dziwić skoro już w 1816 r. Joachim Lelewel, projektując konspekt dziejów państwa i narodu polskiego, wpisał historię polskiego szkolnictwa do grupy podstawowych problemów badawczych ${ }^{12}$. Do tematyki prac publikowanych w tym okresie wpisać można genezę szkół w Polsce, ich rozwój w trakcie wieków średnich, dzieje Uniwersytetu Krakowskiego; zajmowano się także dziejami myśli pedagogicznej średniowiecza oraz jej wpływem na praktykę edukacyjną, pojawiały się też studia na temat wpływu ustawodawstwa kościelnego na rozwój szkolnictwa ${ }^{13}$. Poziom merytoryczny publikacji był bardzo zróżnicowany - od tekstów, które zachowały aktualność naukową po dzień dzisiejszy do niewiele wnoszących przyczynków o dyskusyjnej wartości poznawczej i wątpliwej podstawie źródłowej. Dotychczasowe osiągnięcia nauki polskiej w zakresie dziejów szkolnictwa podsumował Antoni Karbowiak na łamach „Nauki Polskiej" w 1919 r. oraz w formie bibliograficznego zestawienia rok później ${ }^{14}$.

W Polsce niepodległej podjęto starania zmierzające do zintensyfikowania badań historycznych, w tym nad dziejami szkolnictwa i myśli pedagogicznej, jak zauważyła bowiem Helena Orsza-Radlińska „życie narodowe narzuca historykom konieczność zajęcia się dziejami wychowania, oświaty i szkolnictwa w chwili, gdy budują ideały wychowawcze i instytucje pedagogiczne odrodzonej Polski" ${ }^{15}$. Już 5 listopada 1919 r. Ministerstwo Wyznań Religijnych i Oświecenia Publicznego utworzyło Komisję Historyczno-Pedagogiczną do Badania Dziejów Wychowania i Szkolnictwa w Polsce pod przewodnictwem Kazimierza Morawskiego, jako przewodniczącego i Stanisława Kota, jako sekretarza ${ }^{16}$. Zadaniem owego ciała była koordynacja prac źródłowych oraz badań historyczno-oświatowych. Jak trafnie spostrzegła H. Radlińska „dla średniowiecza materiał źródłowy, ogłoszony przez A. Karbowiaka, badania nad literaturą, kulturą, ustrojem, zapoczątkowane studia nad filozofią scholastyczną - czekają na opracowanie, które

11 Zob. K. R a t a j c z a k, Dzieje średniowiecznego szkolnictwa..., s. 284 i n.

12 J. L e l e w e l, Oświecenie i nauki w Polsce aż do czasu zaprowadzenia w niej druku, „Tygodnik Wileński” 1916; przedruk [w:] t e n ż e, Polska wieków średnich, t. IV, Poznań 1851.

${ }^{13} \mathrm{~K} . \mathrm{R}$ a t a j c z a k, Dzieje średniowiecznego szkolnictwa..., s. 286 i n.

${ }^{14}$ A. K a r b o w i a k, Uwagi o wartości, naszem znawstwie i badaniu ojczystych dziejów nauczania i wychowania, „Nauka Polska” 2 (1919), s. 473-479; t e n ż e, Bibliografia pedagogiczna, Lwów 1920.

${ }^{15}$ H. O r s z a-R a d li ń s k a, W sprawie badań historyczno-pedagogicznych. Przegląd zagadnień, „Przegląd Historyczny” 23 (1921), z. 2, s. 50.

${ }^{16}$ Tamże, s. 53. 
tchnie życie w istniejące fragmenty"17. Życzeniu temu stało się zadość, przynajmniej, jeśli idzie o wybrane aspekty.

W czasie IV Zjazdu Historyków Polskich odbywającego się w Poznaniu w dniach 6-8 grudnia 1925 r. podjęto rezolucję dotyczącą intensyfikacji badań nad dziejami szkolnictwa i wychowania. Podkreślono jednocześnie związek historii wychowania z historią kultury i nauki ${ }^{18}$. Problem zreferował wówczas, oraz ponownie w 1929 r., tym razem na łamach „Nauki Polskiej”, Stanisław Łempicki19. Nakreślono wówczas swoisty kwestionariusz badawczy i zakres tematów, które obejmowały dzieje edukacji i myśli pedagogicznej począwszy od antyku chrześcijańskiego po kres epoki średniowiecza, który sytuować będę w dalszych rozważaniach na początek XVI w.

W 1939 r. Marian H. Serejski opublikował w „Przeglądzie Historycznym” studium nad początkami średniowiecznej szkoły, wychodząc od stosunku Kościoła u schyłku antyku do wiedzy starożytnych ${ }^{20}$. Temat ten nawiązywał do opracowania dziejów kultury wczesnego średniowiecza, także w odniesieniu do spraw szkolnych, pióra Alfonsa Dopscha, opublikowanego na łamach tegoż czasopisma w 1932 r. ${ }^{21}$ Obaj uczeni zwrócili uwagę na kształtowanie się w VI-VII w. korporacyjnego charakteru szkół kościelnych, który zdominował ich charakter w ciągu wieków średnich, aż po przełom edukacyjny w stuleciu XIII. Obraz przemiany w sposobie myślenia ludzi Kościoła w tym właśnie stuleciu jest doskonale widoczny w analizie poglądów św. Tomasza z Akwinu na nauki świeckie, dokonanej w 1918 r. przez Apolonię Koperską22. Dodać warto, że pedagogika św. Tomasza cieszyła się pewnym zainteresowaniem ze strony badaczy, czego dowodem jest studium autorstwa Jacka Woronieckiego, które pojawiło się w „Przeglądzie Teologicznym" w roku $1924^{23}$.

Poglądy pedagogiczne i ich praktyczne zastosowanie w szkolnej pedagogice znalazły swych badaczy w dwudziestoleciu międzywojennym w osobach S. Wilka, który opublikował wyniki swych badań odnośnie do św. Bazylego ${ }^{24}$, oraz M. Heitzmanna, który przybliżył polskiemu czytelnikowi ważny traktat Jana Wyc-

17 Tamże, s. 55 .

18 W. S z u l a k i e w i c z (red.), Przedmowa, [w:] Z dziejów polskiej teorii i praktyki edukacyjnej, Toruń 2009, s. 10 i n.

19 S. Ł e m p i c k i, Dzieje szkolnictwa i wychowania w Polsce (Stan badań i postulaty), [w:] Pamiętnik IV Powszechnego Zjazdu Historyków Polskich w Poznaniu 6-8 grudnia 1925, t. 1: Referaty, Lwów 1925, s. 1-18 [paginacja własna]; t e n ż e, Potrzeby historii oświaty, szkolnictwa i wychowania w Polsce, „Nauka Polska” 10 (1929), s. 452-458.

${ }^{20}$ M. H. S e re j s k i, Kościół we wczesnym średniowieczu a saeculis scientia, „Przegląd Historyczny" 35 (1939), s. 89-102.

21 A. D o p s c h, Stan kultury wczesnego średniowiecza, „Przegląd Historyczny” 30 (1932), z. 2, s. 392-397.

${ }^{22}$ A. Ko pers k a, Pogląd św. Tomasza z Akwinu na nauki świeckie, „Ateneum Kapłańskie” 15 (1918), s. 74-80.

${ }^{23} \mathrm{~J}$. W o r o n i e c k i, „Pedagogika parennis” św. Tomasza z Akwinu a pedagogika nowożytna, „Przegląd Teologiczny” 1924, s. 143-160.

${ }^{24}$ S. W i l k, Myśl św. Bazylego o wychowaniu fizycznym człowieka, „Ateneum Kapłańskie” 1934, s. $68-73$. 
liffa De universalibus, popularny w XV w. w środowiskach uniwersyteckich Pragi i Krakowa ${ }^{25}$. Problematykę recepcji zachodnioeuropejskiej myśli w krakowskiej uczelni odnajdziemy także w artykule Kazimierza Dobrowolskiego na temat kultury naukowej w Polsce późnego średniowiecza ${ }^{26}$ oraz w studium K. Michalskiego o filozofii uprawianej w fundacji naukowej Kazimierza Wielkiego, odnowionej w 1400 r. przez Władysława Jagiełłę ${ }^{27}$.

Do nowych tematów, które pojawiały się w pracach o średniowiecznej edukacji, należy bez wątpienia wpływ myśli arabskiej na rozwój nauki i szkolnictwa w Europie łacińskiej. To dzięki kontaktom z arabskimi uczonymi w muzułmańskiej Hiszpanii (zwłaszcza via Toledo i Granadę), w południowych Włoszech i na Sycylii oraz w Syrii i Palestynie następowała recepcja dzieł Arystotelesa, dokonań arabskiej matematyki i medycyny. Dobrym przykładem pracy, o charakterze jednak bardziej popularyzatorskim niż stricte naukowym, jest artykuł Zygmunta Dąbrowskiego, założyciela i redaktora poznańskiego czasopisma „Przeszłość” o kulturze arabskiej i jej wpływie na rozwój nauk ścisłych w średniowiecznej Europie łacińskiej. Autor podkreślał znaczenie arabskich komentarzy do dzieł Arystotelesa, autorstwa Ibn-Siny (Awicenny) i lbn-Raschida (Awarroesa) na recepcję tegoż w nauczaniu uniwersyteckim, a także w rozwoju filozofii scholastycznej ${ }^{28}$. Z. Dąbrowski wskazywał na znaczące inspiracje nauką arabską w szkołach klasztornych i w uniwersytetach paryskim, bolońskim, oksfordzkim począwszy od wieku XIII29.

Dużym zainteresowaniem cieszyły się zagadnienia reformy systemu szkolnego w okresie karolińskim. Zauważmy, że czas publikacji na ten temat zbiegł się z pracami na temat reformy polskiego szkolnictwa, zakończonymi wprowadzeniem tzW. reformy jędrzejewiczowskiej. W ujęciu popularyzatorskim zagadnienie specyfiki szkoły karolińskiej przybliżył Piotr Żukowski w artykule poświęconym znaczeniu reform zainicjowanych przez króla Franków, a od 800 r. cesarza rzymskiego Karola Wielkiego i jego współpracowników, zwłaszcza zaś Alkuina, na funkcjonowanie szkół pałacowych oraz szkół klasztornych i katedralnych ${ }^{30}$. Pozytywny obraz szkoły średniowiecznej kreślił też Stanisław Wesołek w swych opowiadaniach historycznych o życiu w szkole klasztornej w Niemczech ok. roku $940^{31}$ oraz o życiu i pracy nauczyciela $w$ takowej szkole ${ }^{32}$. Pierwszy ze wspomnianych tekstów żywo

${ }^{25}$ M. H e i t z m a n n, Jana Wycliffa traktat „De universalibus” i jego wpływ na uniwersytet praski i krakowski, „Kwartalnik Filozoficzny” 2 (1924), s. 111-156.

${ }^{26}$ K. D o b r o w o I s k i, Studia nad kulturą naukową w Polsce do schyłku XVI stulecia, „Nauka Polska" 17 (1939).

${ }^{27}$ K. M i c h a I s k i, Prądy filozoficzno-teologiczne w Uniwersytecie Jagiellońskim w pierwszej dobie jego istnienia, „Nasza Myśl Teologiczna” 2 (1935), s. 30-47.

${ }_{28}$ Z. Dą b row s k i, Nieco o kulturze Arabów i jej wpływie na nauki ścisłe w średniowieczu, „Przeszłość. Czasopismo Historyczne dla Wszystkich” 3 (1931), nr 2, s. 8-21.

29 Te n ż e, Nieco o kulturze Arabów, „Przeszłość” 3 (1931), nr 3, s. 36-39.

30 P. Ż u k o w s k i, Życie średniowieczne. Pierwszy podręcznik szkolny, „Przeszłość” 3 (1931), nr 6, s. 85-88.

${ }^{31} \mathrm{~S}$. W e s ołe k, $W$ klasztorze niemieckim $w X$ w. Opowiadanie historyczne, „Przeszłość” 4 (1932), nr 1, s. 10-13; nr 2, s. 27-29; nr 3, s. 37-39; nr 4, s. 62-64; nr 5, s. 72-74.

32 Te nże, Nauczyciel średniowieczny (autobiografia), „Przeszłość” 5 (1933), nr 10, s. 145149; nr 11, s. 164-172. 
przypomina znany ze źródeł do dziejów wychowania, chętnie wykorzystywany w dydaktyce, a przypisywany niesłusznie Rabanowi Maurowi, pamiętnik, dotyczący jego edukacji w szkole klasztornej benedyktyńskiego opactwa w Reichenau, opublikowany przez W. Gadowskiego na łamach „Przeglądu Powszechnego” w roku $1889^{33}$. Prezentuje on pogodny, pozytywny obraz życia szkolnego, współpracę dobrotliwego nauczyciela z krnąbrnym uczniem, mimo wszystko zgłębiającego tajniki wiedzy, obraz jakże różny od ponurych wizji średniowiecza, znanych z książki Mroki średniowiecza Józefa Putka, publikowanej po raz pierwszy w roku $1935^{34}$, a później wielokrotnie wznawianej i kształtującej po dzień dzisiejszy niesłuszny i tendencyjny obraz epoki. Mamy natomiast u S. Wesołka uprzejmego i wyrozumiałego nauczyciela, który stara się o urozmaicenie nauki chłopców muzyką, wycieczkami itp. ${ }^{35}$

Tematyka edukacji elit średniowiecznego społeczeństwa polskiego pojawia się w artykułach A. Knot drukowanych na łamach „Życia Szkoły”, poświęconych wychowaniu i kształceniu dzieci królewskich ${ }^{36}$. Do tej kategorii tekstów zaliczyć musimy artykuł zamieszczony w „Przeglądzie Kawaleryjskim”, a poświęcony wychowaniu rycerskiemu ${ }^{37}$. Tekst ten, próbując objąć całość zagadnienia, dotykał aspektów średniowiecznych jedynie w niewielkim stopniu, interesujących czytelników tego branżowego pisma, zapewne wojskowych, ale także krąg polskiej arystokracji. Poniekąd podobne kwestie znalazły się w pracy na temat dziejów wychowania fizycznego począwszy od wieku XV, autorstwa Eugeniusza Piaseckiego ${ }^{38}$.

Zajmowano się także rozwojem nauki, w tym biografiami poszczególnych uczonych, zarówno Polaków, jak i bawiących w naszym kraju obcokrajowców. Przykładem takich prac jest artykuł Bronisława Nadolskiego o działalności Konrada Celitisa w humanistycznym Krakowie ${ }^{39}$ czy też studium Oswalda Balzera na temat studiów i tytułu magistra biskupa krakowskiego i kronikarza Wincentego tzw. Kadłubka ${ }^{40}$. Ogólnie temat rozwoju nauki w Polsce badał Kazimierz Dobrowolski ${ }^{41}$.

${ }^{33}$ Nauka w szkole benedyktyńskiej w Reichenau (IX w.), [w:] Historia wychowania wybór źródet, wyb. i oprac. S. M o ż d ż e ń, cz. II: Średniowiecze, Kielce 1997, s. 17-29. Jest to przedruk tekstu na podstawie: W. G a d o w s k i, Kilka słów o genezie pedagogii, „Przegląd Powszechny” 1889, t. 23, s. $375-390$.

${ }^{34}$ J. P u t e k, Mroki średniowiecza: obyczaje, przesądy, fanatyzm i okrucieństwa w dawnej Polsce, Kraków 1935 i kolejne wydania.

35 S. W e s ołe k, Nauczyciel średniowieczny..., passim.

${ }^{36}$ A. Knot, Z dziejów edukacji dzieci królewskich w dawnej Polsce, „Życie Szkolne” 1932, nr 4-8, s. 157-163, 198-202, 249-251, 293-298.

${ }^{37}$ A. S u j k o w s k i, Szkice z dziejów szkół kawalerii w dawnej Polsce (XI-XIX w.), „Przegląd Kawaleryjski" 1930, nr 7-8.

${ }^{38}$ E. P i a s e cki, Wychowanie fizyczne na Zachodzie w stuleciu XV-XVIII, „Szkoła” 1924, s. $137-146$.

${ }^{39}$ B. N a d o I s k i, Konrad Celtis w Polsce, „Ruch Literacki” 1931, t. 6, s. 257-261.

${ }^{40}$ O. B a I z e r, Magisteriat w Polsce do poł. XIII w. i kwestia magisteriatu Kadłubka, „Sprawozdania Towarzystwa Naukowego Lwowskiego", z. 2, Lwów 1924.

${ }^{41}$ K. D o b r o w o I s k i, Studia nad kulturą naukową w Polsce do schyłku XVI stulecia, „Nauka Polska" 1933, s. 17-148. 
Tradycyjnym już tematem publikacji było życie uniwersyteckie średniowiecza. Autorzy nie ograniczali się li tylko wyłącznie do dziejów uniwersytetu krakowskiego, choć ta tematyka dominowała w analizowanym tu okresie. Alfons Mańkowski badał mianowicie dzieje tradycji uniwersyteckich Pomorza, zapoczątkowanych w drugiej połowie XIV w. staraniami mieszczaństwa, przy aprobacie zakonu krzyżackiego o założenie uniwersytetu w Chełmnie ${ }^{42}$. Dokonał także podsumowania swych badań nad kierunkami podróży studentów wywodzących się z Pomorza do uniwersytetów europejskich. Obrazowi życia naukowego w Polsce Piastów i Jagiellonów poświęcił wnikliwe studium Kazimierz Dobrowolski akcentujący, rzecz jasna, znaczenie uniwersyteckiej fundacji Kazimierza Wielkiego, Jadwigi oraz Władysława Jagiełły dla rozwoju nauki i szkolnictwa ${ }^{43}$. W kontekście badań nad historią nauki w Polsce warto odnotować popularnonaukową pracę autorstwa Jana Kuchty, przybliżającą czytelnikowi zagadnienie rozwoju alchemii i nauk tajemnych w Polsce późnego średniowiecza i początków czasów nowożytnych ${ }^{44}$. Zainteresowaniem badaczy cieszyło się zagadnienie peregrynacji studenckich do Paryża, Bolonii i Padwy ${ }^{45}$. Szczególne zainteresowanie budził przy tym uniwersytet w Padwie, a fakt ten związany był z obchodzonymi wówczas uroczystościami z okazji 700 lat od fundacji uczelni, a ściślej - od migracji studentów z Bolonii do Padwy w 1222 r. ${ }^{46}$ Nieco o polskich studentach podróżujących do zachodnioeuropejskich uczelni w dobie średniowiecza odnajdziemy w artykułach Henryka Barycza, dotyczących jednak generalnie okresu późniejszego ${ }^{47}$. Niemniej odnotowano tu opis polskich wyjazdów naukowych począwszy od wizyt w słynnej szkole Guarino z Werony składanych w 1447 r. przez Jana Lasockiego ${ }^{48}$. Temat mobilności studentów średniowiecznych rozważany był także z pespektywy historii regionalnej, dodajmy, stojącej na znacznie wyższym poziomie merytorycznym w porównaniu z sytuacją z początków XX w. Edmund Klinkowski pisał w „Kronice Gostyńskiej” na temat studentów z Gostynia i okolic na uniwersytetach europejskich i w Krakowie w późnym średniowieczu i początkach ery nowożytnej ${ }^{49}$. Z kolei, podróże pomorskich studentów opisał P. Czaplewski ${ }^{50}$. W pracy E. Klinkowskiego zwraca

\footnotetext{
${ }^{42}$ A. M a ń k o w s k i, Dzieje myśli uniwersyteckiej na Pomorzu, „Roczniki Towarzystwa Naukowego w Toruniu" 32 (1925), s. 1-18.

${ }^{43}$ K. D o b r o w o I s k i, Studia nad kulturą naukową w Polsce do schyłku XVI stulecia, „Nauka Polska" 17 (1933), s. 17-148.

44 J. K u c h t a, Nauki tajemne w Polsce w XV i XVI wieku, „Lud” 27 (1928), s. 75-107.

${ }^{45}$ H. B a r y c z, Zarys historiografii Uniwersytetu Bolońskiego, „Minerwa Polska” 1 (1927), nr 2, s. 105-115; t e nż e, Zarys historiografii Uniwersytetu Padewskiego, tamże, nr 4, s. 311-323.

${ }^{46}$ Z. M o r a w s k i, U kolebki Uniwersytetu Padewskiego, „Przegląd Współczesny” 1922, nr 23; S. Wind a ki e wi c z, W rocznicę padewską (1222-1922), tamże, nr 2.

${ }^{47}$ H. B a ry c z, Z zagadnień podróżnictwa polskiego w dawnych wiekach, „Przegląd Współczesny" 17 (1938), t. 67, s. 68-84; t e n ż e, Podróże polskie do Neapolu w wiekach XV-XVIII, tamże, s. $164-189$.

${ }^{48}$ Te n ż e, Podróże polskie do Neapolu..., s. 175.

${ }^{49}$ E. K I in k owski, Studenci z ziemi gostyńskiej w wieku XV i XVI, „Kronika Gostyńska” 9 (1938), s. 1-8.

${ }^{50}$ P. C z a p l e w s k i, Drogi studentów pomorskich w wiekach średnich, „Pomerania” 1 (1926), s. $4-8$.
} 
uwagę wykorzystanie matrykułów uniwersyteckich z Krakowa i Lipska i umiejętne poprowadzenie studiów prosopograficznych, bowiem autor przebadał losy 87 studentów, w tym 32 pochodzących z Krobi (miasta będącego własnością biskupów poznańskich) i 28 z Gostynia ${ }^{51}$.

Do tekstów badaczy-regionalistów, zajmujących się dziejami edukacji średniowiecznej, zaliczyć należy także studium Ludwika Musioła na temat społecznej pozycji i działalności pozaszkolnej nauczycieli z Wielkopolski, Pomorza i Górnego Śląska ${ }^{52}$. Większość nauczycieli szkół parafialnych i to zarówno miejskich, jak i wiejskich pełniła obowiązki organistów, ale też i kościelnych. Historiografię polską i niemiecką na temat dziejów szkolnictwa na Pomorzu omówił Stanisław Tync w artykule opublikowanym w „Minerwie Polskiej” ${ }^{3}$. W zasadzie do kategorii prac badawczych dotyczących historii regionalnej w aspekcie szkolnictwa zaliczyć możemy stosunkowo zresztą nieliczne artykuły monograficzne na temat szkoły katedralnej we Lwowie ${ }^{54}$ czy też szkoły parafialnej na Nowym Mieście w Toruniu ${ }^{55}$ i szkoły parafialnej w Bieczu ${ }^{56}$.

Co ciekawe, narastający kryzys finansowy i konieczność cięć budżetowych, dotykających także polskie szkolnictwo okresu międzywojennego skłaniały autorów do analiz problematyki finansowania oświaty we wcześniejszych okresach historycznych. Zauważano, że spory wkład w dzieło organizacji i utrzymania placówek edukacyjnych wnosiły osoby prywatne, ale także organizacje religijne i społeczne. Tak było także w wiekach średnich, o czym przekonuje artykuł L. Birkenmajera ${ }^{57}$ oraz prace S. Kościałkowskiego ${ }^{58}$ i A. Wojtkowskiego ${ }^{59}$. Ofiarność przejawiały instytucje świeckie, zwłaszcza dwór królewski i dwory książęce. Szczególnie Uniwersytet Jagielloński cieszył się względami i wsparciem finansowym ze strony prywatnych darczyńców60. Jak zaznaczył L. Birkenmajer „ta ofiarność, zarówno dostojnych w narodzie jak i maluczkich, dotyczyła jednak nie tylko uposażeń katedr i nauczycielskich salariów, magistrów, doktorów i profesorów, lecz owszem obejmowała swoją opieką i troską zarówno uczących się, a więc

${ }^{51}$ E. K I in k o w s k i, Studenci z ziemi gostyńskiej..., s. 8.

52 L. M u s i ał, Nauczyciel a organista na Górnym Śląsku w świetle historycznym, „Minerwa Polska" 1929, s. 156-163.

53 S. Ty n c, Kilka uwag o historiografii szkolnej Pomorza polskiego, „Minerwa Polska” 1920, s. $240-254$.

54 J. S k o c z e k, Dzieje Iwowskiej szkoły katedralnej, „Sprawozdania Towarzystwa Naukowego we Lwowie" 9 (1929), s. 19-22.

${ }^{55}$ E. L e r l e, Dzieje szkoły nowomiejskiej w Toruniu, „Zapiski Towarzystwa Naukowego w Toruniu" 11 (1938), s. 33-53.

${ }^{56}$ R. P a c h u I s k i, Szkoły powszechne w Bieczu w historiograficznym rozwoju. Kartka z dziejów szkolnictwa małopolskiego (XV-XIX w.), „Minerwa Polska” 1927, nr 3, s. 281-290.

${ }^{57}$ L. B i r k e n m a j e r, Urywki z dziejów organizacji nauki polskiej i ofiarności na jej rzecz w Polsce (XI-XX w.), „Nauka Polska” 1923, s. 338-353; 1925, s. 205-225.

58 S. Ko ś c i ałk ow s k i, Z dziejów ofiarności na rzecz nauki i nauczania na Litwie, „Nauka Polska" 1925, s. 241-256.

${ }^{59}$ A. W o j t k o w s k i, Z dziejów popierania nauki i nauczania w Wielkopolsce, na Śląsku i Pomorzu (XV - do 1925), „Nauka Polska” 1927, s. 141-195.

${ }^{60}$ L. B i r k e n m a j e r, Urywki z dziejów organizacji nauki polskiej..., s. 344 i n. 
liczną rzeszę scholarów Jagiellońskiej uczelni”ø1. Wskazywano jednak także znaczący wkład organizacyjny i finansowy ze strony Kościoła w Polsce ${ }^{62}$.

Niektóre zagadnienia poruszane były w pojedynczych publikacjach. Wśród godnych odnotowania z pewnością wymienić trzeba studium E. Lublinerowej dotyczące najstarszych elementarzy, częściowo dotyczące wieków średnich ${ }^{63}$. Również geneza szkolnictwa w naszym kraju pojawia się w jednym tylko artykule, o syntetycznym, dodać należy, charakterze ${ }^{64}$. Kwerenda wykazała także studium A. Wańczura na temat początków szkolnictwa na ziemiach ruskich ${ }^{65}$. Karol Górski z kolei podjął badania nad szeregiem kwestii dydaktycznych i pedagogicznych w samych rozwiązaniach ustrojowych epoki feudalizmu66. Rozwijające się w dwudziestoleciu międzywojennym badania nad rozwojem prawa kanonicznego i ustawodawstwa soborowego, synodalnego zaowocowały także w przyczynkach dotyczących wpływu owego ustawodawstwa na rozwój szkolnictwa w państwie Piastów ${ }^{67}$. Kwestie nas interesujące były jednak w zasadzie tylko sygnalizowane na tle udziału polskiego duchowieństwa w wielkich soborach, zwłaszcza na soborze laterańskim IV w 1215 r., podczas którego podjęto szereg ważnych postanowień dotyczących funkcjonowania szkół ${ }^{68}$. Rolę szkół katedralnych i klasztornych w propagowaniu języka łacińskiego i kultury łacińskiej w Polsce omówił natomiast Wincenty Śmiałek ${ }^{69}$.

Przeprowadzona kwerenda zawartości polskich czasopism wydawanych w okresie międzywojennym skłania do sformułowania kilku wniosków. Widać mianowicie znaczący wzrost ilościowy i jakościowy czasopism naukowych i popularnonaukowych, co było wynikiem zarówno odzyskania niepodległości, a więc i pojawienia się znacznie bardziej sprzyjających warunków dla rozwoju tego typu wydawnictw, jak i przyrost liczby autorów publikujących swe prace, co z kolei należy wiązać ze zwrotem liczby zawodowych historyków, wykształconych na polskich uczelniach. W analizowanym okresie nastąpiła widoczna poprawa jakości merytorycznej publikacji, a także poszerzenie tematyki badawczej w obszarze dziejów szkolnictwa, edukacji i piśmiennictwa pedagogicznego. Mimo że - ze zrozumiałych zresztą względów - okres średniowiecza nie należał do najchętniej

61 Tamże, s. 347 .

${ }^{62}$ B. N o w i c k a, Działalność kulturalna Kościoła gnieźnieńskiego w epoce Kazimierza Wielkiego, „Ateneum Kapłańskie” 28 (1931), s. 49-59, 151-162; L. B i r k e n m a j e r, Urywki z dziejów organizacji nauki polskiej..., s. 342 i n.

${ }^{63}$ E. L u b I i n e r o w a, Historia elementarza (XI-XX w.), „Praca Szkolna” 1938/1939, nr 6, s. $137-142$.

${ }^{64}$ M. M i k u ła, Najdawniejsze szkoły w Polsce, „Życie Szkoły” 1932, nr 11, s. 414-417.

${ }^{65}$ A. W a ń c z u r a, Szkolnictwo Starej Rusi, „Czasopismo Pedagogiczne” 1919/1920, s. 318-370.

${ }^{66}$ K. Górski, Wychowawcze czynniki ustroju średniowiecznego, „Kultura i Wychowanie” 1938, nr 2, s. 104-118.

67 S. Tru c h i m, Rola Kościoła w dziejach Polski (na terenie szkolnictwa), „Sprawozdania Poznańskiego Towarzystwa Przyjaciół Nauk" 3 (1929), s. 57.

68 J. U m i ń s k i, Czwarty sobór laterański i udział w nim Polski, „Przegląd Powszechny” 1925, s. $501 \mathrm{i} \mathrm{n}$.

69 W. Ś m i a łe k, Tradycje kultury i szkoły łacińskiej w Polsce, „Kwartalnik Klasyczny” 1 (1927), z. 3, s. 171-183, zwłaszcza s. 179 i n. 
eksploatowanych zagadnień badawczych oraz, że jedynie niewielka część publikacji dotyczących średniowiecza poświęcona została analizowanej tu tematyce, widać wyraźny postęp w porównaniu do czasów rozbiorów. Polscy historycy i historycy wychowania, wzorując się na aktualnych trendach światowej historiografii, zmierzali do objęcia swymi poszukiwaniami naukowymi możliwie jak najszerszego spektrum zagadnień w celu lepszego poznania przeszłości edukacyjnej. 